\title{
Język w społeczeństwie informacyjnym. Wybrane zagadnienia
}

\section{Selected Issues on a Language in the Information Society}

\author{
Marta Borowiak-Dostatnia \\ (Poznań)
}

\begin{abstract}
In this paper the author asks questions concerning a language: its role. place and function in the information society. Finding the answers she defines the issues by categorizing the concept of a language in relation to its users and the ICT tools used by these users. As a result they fall into three categories: 1. unintentional users, 2. intentional users and 3. pre-users; each with a set of ICT tools assigned to their group.
\end{abstract}

W roku 2009 Komisja Europejska w ramach w ramach 7 Programu Ramowego na nowo zdefiniowała priorytety naukowo-badawcze na lata 2011-2012, wskazując na technologie językowe jako dyscyplinę zasługującą na szczególną uwagę (European Commission ICT Research in FP7 2010). Równolegle do 7PR funkcjonuje Program ramowy na rzecz konkurencyjności i innowacji (CIP), którego jednym z filarów jest Program na rzecz wspierania polityki w zakresie technologii informacyjnych i komunikacyjnych (European Commission Competitiveness and Innovation framework Programme 2010). W ramach tego ostatniego realizowane są projekty wykorzystujace zaawansowaną inżynierię językową w tym m.in. thumaczenie maszynowe czy programy z zakresu NLP. Przywolane fakty oznaczaja, 
że język i technologia są ważnym punktem w prowadzonej przez Unie polityce, stawiającej na rozwój technologii informacyjno-komunikacyjnych, będacych priorytetem w budowaniu spoleczeństwa opartego na wiedzy. Celem niniejszego artykułu nie jest zatem pytanie o wykorzystanie technologii w badaniach nad językiem, a zastanowienie się, jak na poziomie koncepcyjnym można określić jego rolę, miejsce i funkcję w społeczeństwie informacyjnym.

\section{Spoleczeństwo informacyjne - czy wiemy co to jest?}

Pierwszym krokiem potrzebnym do zobrazowania sytuacji jest odpowiedź na pytanie czym jest spoleczeństwo informacyjne (SI). W literaturze ustalono już pewne fakty bezsprzecznie świadczace o czasie i okolicznościach powstania tej formacji, jednak co do jej oficjalnej i jednomyślnej klasyfikacji, naukowcy nie sa zgodni.

Narodziny SI zaczęly się od nazwy, od terminu, który stał się w Japonii hasłem sztandarowym, przyświecającym wszelkiej aktywności gospodarczej. Twórcą pojęcia jest etnolog Tadao Umesao, który w 1964 r. w swoim artykule stwierdził, że spoleczeństwo osiagnie najwyższy stopień rozwoju, gdy zmiany w nim zachodzące opierać się będą na technologii informacyjnej i przetwarzaniu informacji (Kacperek Papińska 2008). Kilka lat później Yoneji Masuda wspólpracując z organizacją rządową opracowal czteroetapowy plan o charakterze gospodarczo-spolecznym, którego realizacja rozlożona byla na ponad 50 lat i który opieral się na 5 aspektach zarządzania informacja: na jej gromadzeniu, przechowywaniu, przetwarzaniu, przekazywaniu i wykorzystaniu (Szewczyk 2007). Niekiedy ww. aspekty uważa się za najbardziej lapidarną definicję SI. Sukces Japonii, a więc stworzenie do 2000 r. SI, upatrywać należy w holistycznym podejściu do problemu. Realizowana strategia byla ideologicznie i politycznie spójna; wykorzystywala tradycje i mocno osadzone w społeczeństwie japońskim cechy kulturowe.

Rozwój SI w USA mial inny charakter i przebiegal dwutorowo. Z jednej strony wiązal się z analizą najświeższych wydarzeń o cha- 
rakterze spolecznym oraz analizą danych sektorów gospodarczych, z drugiej zaś z rozwojem i postępem technologicznym, wpisującym się w polityczne cele dotyczące obronności kraju i rywalizacji ze Związkiem Radzieckim. Przykladem dzialań na tym polu jest powstanie w kręgach wojskowych sieci ARPANET - zalążka Internetu. W latach 80 . sytuacja polityczna ulegla zmianie, w konsekwencji czego badania związane $\mathrm{z}$ obronnością kraju nie znalazly uzasadnienia. Pieczę na dalszym rozwojem technologii informacyjnych przejęly ośrodki naukowe, w tym uniwersytety (Krzysztofek/ Szczepański 2002).

Równolegle do badań wojskowych, realizowane byly cywilne projekty badawcze, prowadzone przez naukowców, obserwujących i analizujących zmiany zachodzace w społeczeństwie i gospodarce USA po II wojnie światowej. Wyniki badań Fritza Machlupa i Marca Porata (Crawford 1983) pokazaly, że sektor informacyjny wkrótce (mówimy o latach70.) przekroczy 50\% GNP (Gross National Pro$d u c t$ ) amerykańskiej gospodarki. Będacy podobnego zdania Daniel Bell (Dobrowolski 2005) wskazywal, że na plaszczyźnie ekonomiczno-społecznej pojawil się nowy towar. Jest nim wiedza i informacja. Posiadanie tego towaru odgrywało taką rolę jak żywność w spoleczeństwie agrarnym czy praca i kapital w spoleczeństwie przemyslowym ( ibid.). Zdania naukowców, transformacje spoleczne oraz postęp technologiczny, dodatkowo utwierdzaly w przekonaniu, że oto pojawila się nowa formacja cywilizacyjno-kulturowa-spoleczeństwo informacyjne.

Jednak współcześni socjologowie nie sa zgodni co do tej kwestii. Bezsprzecznie postęp technologiczny wplynąl na zewnętrzne i wewnętrzne struktury rzadzące światem, jednak nie można jednoznacznie stwierdzić, że nastapil nowy rozdzial w historii cywilizacji. Wydaje się bowiem, że SI funkcjonuje i rozwija się równolegle obok innych, podobnych form takich jak spoleczeństwo sieci, ryzyka czy nadmiaru informacji, a każde $z$ nich czerpie $z$ nadrzędnej jednostki jaka jest społeczeństwo postindustrialne. O ile Malchup, Porat czy Bell komentowali zastaną rzeczywistość, późniejsi naukowcy tacy jak Weber (2002) czy Castellas (2007), odnoszą się do zjawiska z pewnej, bo niemalże 20-letniej perspektywy czasowej. Stanowisko 
tych ostatnich jest bardziej krytyczne i klasyfikuje społeczeństwo informacyjne albo jako kontynuację społeczeństwa postindustrialnego, albo jako jego uzupelnienie.

O skali niezgody, różnorodności terminologii i idei uwzględniajacych rozwój technologiczny świadczy fakt, że na przestrzeni 1950-2002 średnio co dwa lata pojawiał się co najmniej jeden nowy termin określający zmiany o charakterze politycznym i spolecznogospodarczym (Nowina Konopka 2006). Wśród proponowanych terminów byly: samotny thum (Reisman 1950), ekonomia wiedzy (Machlup 1962), globalna wioska (McLuhan 1964), era technotroniczna (Brzeziński 1970), mediokracja (Philips 1975), czlowiek Turinga(Bolter 1984), spoleczeństwo sieciowe (Castellas 1996), spoleczeństwo nadmiaru informacji (Marten 2002; za: Nowina Konopka 2006).

Dlaczego więc tyle mówi się o społeczeństwie informacyjnym? Dlatego, że ono istnieje bez względu na socjologiczną klasyfikacje formacji. Zwlaszcza w naszym kręgu spoleczno-kulturowym, w którym czlonkostwo w Unii jest mocno akcentowane, a Polska caly czas wydaje się nadganiać zaległości i pretendować do miana kraju rozwiniętego. Proces cyfryzacji, doskonalenia umiejętności z zakresu IT, wykorzystanie narzędzi ICT w naszym kraju jest jeszcze raczej w fazie adaptacji, jednak na poziomie międzynarodowym SI jest rzeczywistością. Wymienione wyżej programy europejskie są tylko namiastką tego, nad czym pracują specjaliści z zakresu ICT. Z kolei w powszechnym rozumieniu odbiór hasla: spoleczeństwo informacyjne, dzięki mass mediom i literaturze popularno-naukowej, to w dużej mierze produkty, które zawierają pierwiastek technologii i/lub związane sa z Internetem. Od strony lingwistycznej, bez dogłębnej analizy powiedzieć można, że są to produkty z przedrostkiem ,e", świadczącym o elektronicznym charakterze obiektu. Na poziomie gospodarczo-ekonomicznym mamy więc: e-finanse, e-bankowość, e-administracje; spolecznym: e-tożsamość, e-życie, e-obywatel; kulturalnym: e-gazety, e-kino, e-sztukę, etc. Przykłady można mnożyć przyporzadkowujac je do dowolnej kategorii. Jedynym kryterium jest obecność obiektu w sieci. 


\section{Język w spoleczeństwie informacyjnym}

Czy język jest również częścią SI? Czy można mówić o obecności języka w SI? Jeżeli tak, to jak ta obecność się przejawia?

Bezsprzecznie choćby na podstawie wyżej przedstawionych faktów stwierdzić należy, że polączenie takie ma miejsce i co więcej, jest mocno eksplorowane przez naukowców z dziedziny informatyki i językoznawstwa. Jednak obecność takiego polączenia, czy wręcz symbiozy może być różnie rozumiana na poziomie koncepcyjnym. Poniższa interpretacja jest jedną z możliwych ${ }^{1}$.

Definicja języka w SI musi czerpać z przyjętej i akceptowanej definicji formacji. Odwohując się do przedstawionych przed momentem e-produktów zauważyć można, że umieszczenie SI w pewne sztywne ramy pojęciowe sprawi trudności ze względu na jego wieloaspektowość. Kwestia definicji jest oddzielnym, autonomicznym problemem, nad którym pochylają się naukowcy. W literaturze polskiej w latach 1998-2005 pojawilo się kilka charakterystyk, z czego najczęściej cytowane są te, opracowane przez Juszczyka, Kubicka, Klasa i Sienkiewicza. Najczęściej definicje podkreślają charakter SI pod kątem wartości, którą wnosi ono do danej dyscypliny czy obszaru zainteresowan. Bez względu na wybór definicji, jedna rzecz stanowi absolutna podstawę rozwoju SI: technologie informacyjno-komunikacyjne. W kontekście języka zatem, można przyjąć, że jest to:

(...) taka forma organizacji społecznej, w której język jest meta-narzędziem w procesie komunikacji oparty m na narzędziach ICT ${ }^{2}$. Proces komunikacji skrócony zostaje do minimum, przekazywany komunikat dociera do zdefiniowanego odbiorcy w żądanym przez nadawcę lub odbiorcę języku,

1 Przedstawiona w artykule interpretacja autorki jest rezultatem jej pracy nad rozprawą doktorską.

2 Pojecie: narzędzia ICT w rozumieniu autorki jest pojęciem złożonym, uwzględniającym podział ich ze względu na dostępność do sieci. Zagadnienie to, zwłaszcza w kontekście wykorzystania ICT do pracy z językiem, pretenduje do osobnej pracy w związku z czym przywołane w niniejszej pracy narzędzia należy przyjąc jako przykładowe, nie zamykające listy. 
a rozwiązania technologiczne mają charakter szablonów gotowych do zastosowania w komunikacji globalnej.

Powyższa definicja choćby ze względu na umieszczenie w niej zagadnień dotyczacych technologii informacyjno-komunikacyjnych już pozwala na akceptację obecności języka w SI. Jednak nie jest to jedyny czynnik. Znaczącym punktem tej obecności jest funkcja komunikacyjna języka. Wydaje się bowiem - co zostanie również poświadczone w dalszej części - że efektem pracy z wykorzystaniem technologii są narzędzia wspomagajace proces komunikacji. Konsekwentnie więc możliwe jest przeprowadzenie klasyfikacji obecności języka w SI biorąc pod uwagę zastosowane narzędzia. Kryteriami tej klasyfikacji są użytkownicy oraz narzędzia ICT przez nich używane. Uznano, że w spoleczeństwie informacyjnym można mówić o trzech grupach użytkowników: użytkownicy nieświadomi, użytkownicy świadomi oraz pre-users ${ }^{3}$.

\subsection{Użytkownicy nieświadomi}

Użytkownicy nieświadomi to tacy, którzy w swojej komunikacji werbalnej wykorzystują narzędzia Web 2.0. Stwierdzenie to, jak również obie przywołane nazwy wymagaja jednak słowa komentarza.

Otóż nazwa ,użytkownicy nieświadomi" jest echem terminologii zaczerpniętej od Prensky'ego (Prensky 2001), który uważa, że wspólcześni użytkownicy sieci będący w wieku szkolnym to native speakerzy języka cyfrowego. Nawiązując do terminu pokazuje analogie między pojęciami: tak, jak dla native speakera język rodzimy jest narzędziem - powiedzmy - wrodzonym, tak też osoby z omawianej grupy używają technologii jako narzędzia, które od zawsze było integralna częścią ich świata. Druga grupa użytkowników to osoby, które nauczyly się posługiwać narzędziami ICT - albo dla potrzeb wlasnych albo zawodowych - i na tyle opanowaly umiejętności IT, że technologia nie jest dla nich wyzwaniem, a tak samo

Nazwę trzeciej grupy proponuję po angielsku, gdyż odpowiednik polski lub inna terminologia nie oddają w pełni charakteru pracy tych użytkowników. 
naturalnym narzędziem czy przedmiotem jak zegarek, dlugopis czy kubek do kawy.

Z kolei nazwa Web 2.0. ma charakter żargonowy i przez krytyków określana jest raczej jako termin marketingowy, powolując się na założenia dotyczące działania Web 2.0., które pokrywają się z zalożeniami pracy Web 1.0. Tym niemniej, różnica polega glównie na charakterze narzędzi, które są bardziej dynamiczne i demokratyczne, zwłaszcza w kontekście komunikacji. Zmiana, jaka zaszla dotyczy głównie charakteru interakcji, opartej już nie na linii: użytkownik serwer, a użytkownik - użytkownik. Glównymi narzędziami Web 2.0 są zatem: portale społecznościowe, blogi, chatroomy (listy dyskusyjne), strony Wiki, podcasty, kanaly RSS, komunikatory i inne.

Kryterium klasyfikacji tej grupy zaklada, że każde z narzędzi używane jest w innym celu niż nauka języka obcego. Intencją ich wykorzystania jest nadanie/odbiór komunikatu. Jednak zanim nastapi jakakolwiek aktywność ze strony użytkownika, najpierw wybierze on odpowiednie do zamierzonego celu narzędzie, które z kolei będzie narzędziem w odpowiedniej wersji językowej. W związku z tym powiedzieć można, że język występuje w tej grupie w funkcji meta-narzędzia, które określa i definiuje wersje językową (interfejs) danego narzędzia. Potencjalnym celem uczestnika portalu społecznościowego, jego obecności na blogach czy listach dyskusyjnych jest przekazanie lub pozyskanie informacji. Znaczna cześć (o ile nie wszystkie) z tego typu narzędzi ma charakter globalny (Facebook, Wikipedia, Twitter, Blogger), co pod względem językowym wiąże się z 2 rzeczami. Pierwsza z nich to wspomniana już aplikacja w danym języku, druga to charakter przekazywanego komunikatu. Jeżeli odbiorca jest osoba spoza obszaru językowego nadawcy, komunikat przekazany będzie najprawdopodobniej w języku angielskim, ewentualnie innym języku naturalnym w zależności od docelowego nadawcy (portugalskim, niemieckim, chińskim). W tak przekazanym komunikacie, „ćwiczony” jest przez użytkownika caly wachlarz kompetencji językowych, (niekoniecznie dotyczacych języka obcego) bez jego świadomej woli czy intencji. Mamy zatem pisanie (blogi, fora), mówienie (komunikatory np. skype czy autorskie podcasty), słuchanie (videosharing, onlie streaming) 
i czytanie (listy dyskusyjne, blogi, portale). Tak więc glównym aspektem wykorzystanie języka przez tę grupe jest jego naturalne i dynamiczne zastosowanie przy wykorzystaniu narzędzi ICT, w tym głównie narzędzi Web 2.0.

\subsection{Użytkownicy świadomi}

Druga grupę stanowią użytkownicy świadomi, a więc osoby, które celowo zajmują się językiem. Do tej grupy zaliczyć można nauczycieli języka (w dużej mierze chodzi tu o język obcy) uczniów, studentów, czyli innymi słowy: osoby uczące się. Wykorzystanie przez nich języka wiąże się przede wszystkim z zastosowaniem oprogramowań CALL (Computer Assissted Language Learning). Ta grupa narzędzi językowych miała swój poczatek w latach 60 . W chwili obecnej zagadnienia zwiazane z CALL w dydaktyce i metodyce nauczania języków obcych mają swoich zwolenników, tworzących swego rodzaju spoleczność, która prezentuje wyniki badań na corocznych konferencjach poświęconych tej tematyce, takich jak prestiżowa EUROCALL (European Association for Computer-Assisted Language Learning 2010). Warto również w tym miejscu zauważyć, że CALL, obok dydaktyki czy glottodydaktyki, pretenduje do zagadnienia, które powinno znaleźć się w obowiązkowym programie kształcenia przyszlych nauczycieli. Przyczyn jest kilka, ale najważniejsza dotyczy technologicznego charakteru tej grupy, traktowanej jako pomoc dydaktyczna. Klasyfikacja CALL przedstawiana jest różnie; najczęściej jako podgrupa narzędzi ICT lub ich uzupelnienie. Taka klasyfikacja jest jak najbardziej pożądana ${ }^{4}$ bowiem w skład narzędzi CALL, oprócz specjalistycznych aplikacji typu (generic) software (Davies et al. 2010), wchodzi również cała gama oprogramowań opartych na systemie Microsoft Windows (np. Word czy Power Point),

$4 \quad$ Niekiedy jednak myli się pojęcia ICT i CALL, w efekcie czego stosuje się te terminy zamiennie. Nieporozumienie wynika najpewniej z zestawów narzędzi, które moga być takie same dla obu grup. Należy jednak pamiętać, że nie wszystkie narzędzia ICT stosowane są tylko do nauczania języków obcych, za to narzędzia CALL - z racji definicji - tak. 
która może być wykorzystana w nauczaniu języków obcych, oraz narzędzia Web 2.0.

Przypomnieć należy, że osoby zaczynajace lub kontynuujace naukę języka obcego (chodzi tu o pewną granicę wiekowa), nie znaja świata innego niż ten bombardujący ich bodźcami technologicznymi. Chcąc nawiązać kontakt, nauczyciel (w zasadzie nie tylko języka obcego) i uczeń muszą mieć tą samą plaszczyznę komunikacji, ten sam punkt odniesienia, czyli ten sam język i terminologię. Nauczyciel musi znać świat, także ten wirtualny ucznia, by z powodzeniem nawiązać z nim wspólpracę. Zastosowanie narzędzi CALL pozwala wyjść z ram książkowych i użyć materialów online, które w możliwie najlepszy sposób odzwierciedlają naturalne środowisko językowe. I wreszcie - oprogramowanie wspomagajace naukę jest odpowiedzią na wymogi wspólczesnego świata, w którym technika odgrywa znacząca rolę. Brak należytej uwagi czy wręcz ignorowanie CALL w tym kontekście, to krok wstecz zarówno w zawodowym rozwoju nauczyciela, jak i intelektualnym rozwoju ucznia.

Do CALL wchodzą wspomniane narzędzia Web 2.0. Jednak wykorzystanie ich w tej grupie ma inny charakter, niż w grupie pierwszej. Z punktu widzenia ucznia/nauczyciela jako użytkownika, blogi, nagrania audio czy prezentacje multimedialne sa świadomym i celowo wybranym narzędziem dydaktycznym, którego zadaniem jest rozwijać konkretne kompetencje językowe. Dodatkowo ma ono pomóc uczniowi poruszać się po wirtualnym świecie ćwicząc jego umiejętności z zakresu IT. W tym kontekście, nauka języków obcych wpisuje się w szerszy nurt edukacji informatycznej. Z perspektywy nauczyciela zaś, narzędzia CALL typu authoring programs oraz narzędzia z grupy Web 2.0. to możliwość przygotowania materiałów dydaktycznych skrojonych na potrzeby konkretnej grupy czy ucznia. Harmonijnie i spójnie przeprowadzone zajęcia podnosząjakość i atrakcyjność lekcji. I choć tworzenie autorskich materiałów jest dość czasochłonne, to późniejsza ich modyfikacja znacznie prostsza. Narzędzia CALL to również wsparcie merytoryczne, baza pomyslów i materiałów dla nauczycieli, czego przykladem może być portal: classroom $20 . c 0 m$

Świadomi użytkownicy języka celowo wykorzystujący technologię to także inna grupa zawodowa. Są nią thumacze, którzy w chwili 
obecnej mają coraz lepsze narzędzia w postaci opracowanych korpusów językowych i baz danych, wspomagające ich pracę. Dostępność do specjalistycznych oprogramowań thumaczeniowych, w tym do thumaczenia maszynowego pozwala skrócić czas pracy tlumacza. Badania prowadzone w zakresie MT (Machine Translation) zmierzają do tego, by m.in. ulatwić pierwszy etap thumaczenia, jakim jest szkic dokumentu w języku docelowym (Arnold et al. 1994). Weryfikacja tlumaczenia oraz jego korekta najprawdopodobniej jeszcze przez jakiś czas nie będzie możliwa bez udzialu tlumacza. Tym niemniej thumaczenie maszynowe (automatyczne) to dziedzina językoznawstwa komputerowego, która ma silną pozycję w przemyśle językowym, o czym świadczy uczestnictwo w międzynarodowych projektach (w tym unijnych) dużych firm komercyjnych takich jak: Xerox, France Telecom czy Nokia. Systemy MT to także ważny skladnik w kolejnej, trzeciej grupie użytkowników.

\subsection{Pre-users}

Pre-users to osoby związane z technologiczną stroną materialów dydaktycznych oraz narzędziami wspomagajacymi pracę z językiem. Są to trzy kategorie osób. Pierwsza stanowią ci, którzy pracuja nad oprogramowaniami CALL jednak w fazie ich projektowania, a więc sa to prace o charakterze informatycznym, na przyklad nad platforma/pakietem wykorzystanym w dalszym etapie przez nauczycieli jako authoring program; w sklad drugiej grupy wchodza osoby zajmujące się inżynierią językową: w skład trzeciej - osoby pracujące w przemyśle technologii językowych (producenci, firmy komercyjne z branży telekomunikacyjnej). Efektem pracy ich wszystkich są oczywiście narzędzia typu CALL oraz narzędzia z tzw. Human Language Technologies, a więc: narzędzia przetwarzania języka naturalnego, syntezy mowy, rozpoznawania mowy, thumaczenia maszynowego, tagger, analizator semantyczny, analizator składniowy i inne.

Nadrzędnym celem prowadzonych prac jest upowszechnienie ich efektów w postaci ogólnodostępnych narzędzi wspomagających proces komunikacji i posługiwania się językiem obcym. Wachlarz 
opracowywanych narzędzi typu HLT jest coraz szerszy, a jakość i wynik końcowy pracy specjalistycznych aplikacji językowych coraz lepszy. Przywołane poniżej najpopularniejsze narzędzia to zaledwie zarys tego, czym zajmuje się inżynieria językowa.

Zaczynając od thumaczenia mechanicznego, stwierdzić należy, że nadal jest to dalece niedoskonale narzędzie i użycie choćby najlepszych translatorów daje często niesatysfakcjonujace wyniki. Tym niemniej thumaczenie maszynowe ma swoje zastosowanie jako narzędzie z pokaźną bazą fraz i zwrotów często używanych (na przykład w oficjalnych pismach urzędowych). Szacuje się, że taka baza pozwala thumaczowi zaoszczędzić do $80 \%$ czasu pracy. Kolejnym narzędziem jest syntezator mowy, którego zastosowanie znane jest z takich urządzeń jak elektroniczne słowniki (mówiące slowniki) czy nawigacje GPS. Godnym polecenia jest polski syntezator mowy IVONA, który ma dość szerokie zastosowanie w przemyśle i cieszy się uznaniem w środowisku naukowym i w przemyśle międzynarodowym ${ }^{5}$. Mniej rozwiniętym jednak także popularnym jest narzędzie rozpoznawania mowy, które co prawda ma jeszcze ograniczone zastosowanie jednak znamy je z aplikacji telefonów komórkowych, które pozwalają glosowo wybrać menu. Narzędzia te sa przedmiotem badań wielu projektów unijnych (LUNA, CLASSiC, EMIME), które lączą ideę rozpoznawania mowy z thumaczeniem maszynowym. Do kompletu narzędzi dodać należy analizator skladniowy (tzw. parser), wykorzystywany choćby w zapytaniach slownikowych (wynik zapytania + konotacje gramatyczne lub składniowe) czy w narzędziach typu grammar checker. Aplikacje te są stalym elementem w niektórych powszechnie stosowanych oprogramowaniach, takich jak edytor tekstu.

Ograniczenia związane z badaniami nad narzędziami z grupy HLT oraz ich rozwojem podyktowane są bogactwem języka, jego dynamiką i regulami poprawności. Największe trudności sprawiają konotacje emocjonalne i intencjonalne nadawcy komunikatu. Ta sama fraza brzmi bowiem inaczej w stanie euforii i inaczej w gniewie. Dobry program NLP powinien rozróżnić taki komunikat. To

IVONA 2010, Wdrożenia, URL: http://www.ivona.com/casestudies.php [dostęp: $30.04 .2010]$ 
jednak wiąże się z opracowaniem ogromnej bazy danych. Kolejnym znaczacym utrudnieniem zwlaszcza w thumaczeniu maszynowym jest fraza (slowo), które mimo znanego dla systemu ,wyglądu” ma w danym kontekście inne znaczenie: przykladem jest slowo zamek. Następnym problemem jest rozpoznanie sygnalu mowy (kwiat vs. kfiat) oraz intonacja, akcent, rytm, aspekt pragmatyczny i semantyczny (morze vs. może) - z takimi problemami powinien uporać się dobry syntezator mowy, który w końcowym efekcie wyprodukuje komunikat w miarę naturalnie brzmiącym języku. Z kolei cechy osobowościowe nadawcy komunikatu są przeszkodą w dynamicznym rozwoju narzędzi rozpoznawania mowy. Inaczej bowiem pracuje system bazujący na tzw. dependent speaker, czyli osobie którą system zna, która „nagrywa” slowo/frazę w różnych wersjach; inaczej na tzw. independent speaker, który zaprojektowany jest dla dowolnego mówcy (Gupta/Schulze 2010).

Można zaryzykować stwierdzenie, że liczba problemów związanych z rozwojem technologii językowych jest proporcjonalna do możliwości ich zastosowania. Tym niemniej niektóre uczelnie europejskie zauważyły jak dynamiczna, kusząca pod względem naukowo-badawczym i również od strony komercyjnej atrakcyjna jest inżynieria językowa. Na Københavns Universitet (Uniwersytet Kopenhaski, Dania) czy Radboud Universiteit (Uniwersytet Radboud, Nimegen, Holandia) proponowane są kierunki o specjalizacji: technologia językowa ${ }^{6}$; w innych krajach dzialalność naukowobadawczą prowadzą specjalne ośrodki takie jak Language Technology Research (Uniwersytet Helsiński, Finlandia) czy Centre for Speech Technology Research (Uniwersytet Edynburski, Szkocja). Tym sposobem ww. kraje ksztalcą specjalistów, którzy w dluższej perspektywie zdominują naukową i komercyjną stronę przemysłu technologii językowych.

Na podstawie analizy uniwersyteckich programów kierunków filologicznych przeprowadzonej w ramach pracy nad rozprawa doktorska. 


\section{Wnioski}

Przedstawiona interpretacja obecności języka w SI porusza głównie zagadnienie dotyczące jej klasyfikacji. Klasyfikacja ta obejmuje trzy grupy użytkowników, przyporządkowując jednocześnie grupę narzędzi ICT oraz funkcję, w jakiej język występuje. W aplikacjach CALL, będących zarówno w drugiej jak i w trzeciej grupie, język spelnia funkcje meta-narzędzia, które determinuje charakter calego oprogramowania. Funkcje komunikacyjna zaobserwować można przede wszystkim w grupie pierwszej oraz trzeciej, w której jakość komunikacji wielojęzycznych użytkowników jest nadrzędnym celem prowadzonych badań. Funkcja edukacyjna znajduje zastosowanie w grupie drugiej.

W ogólnym obrazie SI należy pamiętać o tym, że rozwój formacji to nie tylko aktywność sektora ekonomicznego i wykorzystanie w nim rozwiązań informatycznych; to także zastosowanie technologii w naukach humanistycznych. Zgodnie ze spoleczno-edukacyjnymi założeniami SI, każdy jego czlonek powinien posiąść podstawowe umiejętności z zakresu IT. W naukach humanistycznych, w tym na kierunkach filologicznych, należy zatem docenić narzędzia ICT i wykorzystać je do badań nad językiem. Należy też zastanowić się, czy podązając śladem Danii i Holandii nie warto zaproponować studentom nowe kierunki uniwersyteckie, które wykształcą specjalistów w stosunkowo nowej i prężnie rozwijającej się dyscyplinie, za jaką można uważać inżynierię językową.

\section{Bibliografia}

Arnold, D.J./Balkan, Lorna/Meijer, Siety/Humphreys, R.Lee/Sadler, Louisa (1994): Machine Translation: an Introductory Guide. London: Blackwells-NCC.

Castellas, Mauel (2007): Spoleczeństwo sieci. Warszawa: PWN. 
Crawford, Susan (1983): "The Origin and Development of a Concept: The Information Society". Bulletin of the Medical Library Association 71 (4).

Davies, Graham/Walker Ros/Rendall, Heather/Hewer, Sue (2010): "Introduction to Computer Assisted Language Learning (CALL). Module 1.4". [w]: Davies Graham (ed.): Information and Communications Technology for Language Teachers (ICT4LT). Slough: Thames Valley University. URL: http://www.ict4lt.org/en/en_modl-4.htm [dostęp: 22.03.2010].

Dobrowolski, Zdzislaw (2005): ,Koncepcja spoleczeństwa informacyjnego Daniela Bella" [w]: Sosińska-Kalata, Barbara/Przastek-Samokowa, Maria: Od informacji naukowej do technologii spoleczeństwa informacyjnego. Warszawa: Wyd. Stow. Bibliotekarzy Polskich - seria Nauka-Dydaktyka-Praktyka 78, 87-106.

European Association for Computer-Assisted Language Learning (2010): "EUROCALL Conferences". URL: http://www.eurocall-languages. org/confs/index.html [dostęp: 26.03.2010].

European Commission Competitiveness and Innovation framework Programme (CIP) (2010): "Information and Communication Technologies Policy Support Programme (ICT-PSP)". URL: http://ec.europa.eu/cip/ ict-psp/index_en.htm, [dostęp: 26.09.2010].

European Commission ICT Research in FP7 (2010): "Language technologies". URL: http://cordis.europa.eu/fp7/ict/language-technologies/fp 7ict_en.html [dostęp: 26.08.2010].

Gupta, Piklu/Schulze, Mathias (2010): "Human Language Technologies (HLT). Module 3.5”. [w]: Davies Graham. (ed.): Information and Communications Technology for Language Teachers (ICT4LT). Slough: Thames Valley University. URL: http://www.ict4lt.org/en/en_mod3-5. htm [dostęp: 02.05.2010].

Kacperek Papińska, Joanna (2008): Spoleczeństwo informacyjne. Warszawa: PWN.

Krzysztofek, Kazimierz/Szczepański, Marek S. (2002): Zrozumieć rozwoj: od spoleczenstw tradycyjnych do informacyjnych. Katowice: Wydawnictwo Uniwersytetu Śląskiego.

Nowina Konopka, Maria (2006): „Istota i rozwój spoleczeństwa informacyjnego". [w]: Bialoblocki, Tomasz: Spoleczeństwo informacyjne. Istota. Rozwój. Wyzwania. Warszawa: WAiP.

Prensky, Marc (2001): "Digital Natives, Digital Immigrants". [w]: On the Horizon 9 (5). Lincoln: NCB University Press, URL: http://www. marcprensky.com [dostęp: 09.03.2010] 
Szewczyk, Agnieszka (2007): „Spoleczeństwo informacyjne - nowa jakość życia społecznego". [w]: Szewczyk, Agnieszka: Społeczeństwo informacyjne - problemy rozwoju. Warszawa: Difin.

Webster, Frank (2002): Theories of the Information Societies. Second Edition. Oxon USA and Canada: Routledge. 